\title{
電気二重層キャパシタ用電極主材としての賦活 ケッチェンブラックの容量特性
}

\section{Capacitance properties of activated Ketjenblack as an electrode active-material for an electric double layer capacitor}

\author{
白石壮志 ${ }^{a), *}$, 川口 忍 ${ }^{a)}$, 島袋 出 $^{a)}$, 畠山義清 ${ }^{a)}$
}

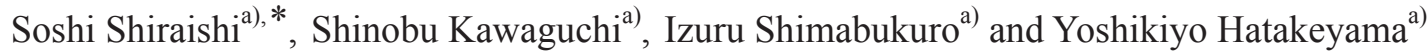

\begin{abstract}
Ketjenblack (KB), which is a mesoporous carbon black, can be used as electrode active material for an electric double layer capacitor (EDLC). This paper addresses the capacitance properties of the activated KB with a high specific surface area as the electrode active material. The mesopore volume in $\mathrm{KB}$ was decreased by $\mathrm{KOH}$-activation, while the micropores were developed to increase the specific surface area. As a result, the $\mathrm{KOH}$-activated $\mathrm{KB}$ showed a higher volumetric capacitance as an EDLC electrode compared with the pristine KB. Additionally, it was also shown that the nitrogen-doping of the KOH-activated KB by nitrogen-monoxide produces a better volumetric capacitance and an ability to tolerate high voltages compared to the pristine KB electrode.
\end{abstract}

KEYWORDS : Ketjenblack, Activation, Electric double layer capacitance, Nitrogen dope, Durability

\section{1. 緒 言}

ケッチェンブラック (Ketjenblack, KB) は一次粒子が中空シェル 構造をもつカーボンブラックであり, メソ孔が発達したカーボン ナノ粒子とみなすことができる ${ }^{1)-3)}$ 。電子伝導性に優れることか ら, $\mathrm{KB}$ は樹脂コンパウンド, 電池・電気化学キャパシタの電極 の導電補助材として広く使われている ${ }^{1)}$ 。例えば，KBのような 導電性カーボンブラックを数パーセント添加することで, 電極の 内部抵抗を大きく低減できる ${ }^{4)}$ 。田島らはKBが他のカーボンブ ラックに比べて優れた内部抵抗低減効果を示すことを報告して いる5),6。また，KBは他のカーボンブラックに比べて比較的高い 比表面積を有していることから, 電気化学キャパシタの一つであ る電気二重層キャパシタ (Electric Double Layer Capacitor, EDLC) の電極主材としての検討もなされている7)-10)。しかしながら，高 比表面積グレードでも $1000 \mathrm{~m}^{2} \mathrm{~g}^{-1}$ 程度の比表面積であるため, キャパシタ用の活性炭と比較すれば $\mathrm{KB} の$ 電気二重層容量は低い 傾向にある。KBをキャパシタ電極主材として用いるためには何 かしらの方法でさらに高比表面積化することが望ましい。

KBは合成ガスの製造を目的とした重質油のガス化プロセス における副生成物であり，製造プロセス中に炭素マトリクスも ガス化されることで細孔構造が発達する ${ }^{2), 11) 。 こ の こ と は ， K B ~}$ が活性炭と同様に賦活によって細孔構造が発達しやすい結晶性 の比較的低い炭素マトリクスで構成されていることを表して いる。したがって，一般的なガス賦活あるいは薬品賦活処理を
二次的に施せばKBの高比表面積化は可能である。Maltsevaら は，KBを空気賦活して，希硫酸電解液中での電気二重層容量 の評価を行っている ${ }^{10)}$ 。しかしながら, 水蒸気賦活, $\mathrm{CO}_{2}$ 賦活, $\mathrm{KOH}$ 賦活などの一般的な賦活を行い，さらにはエネルギー密 度的に有利な有機系電解液を用いて容量評価を行った例につい ては著者らが調べた限りでは報告例がない。

このような背景から，本研究では $\mathrm{KOH}$ 賦活ならびに $\mathrm{CO}_{2}$ 賦 活によって KBの比表面積を増加させることで，KBを電極主 材とした有機電解液系EDLCの容量特性の向上を試みた。ま た，EDLCにおいては，エネルギー密度ならびに信頼性の観 点から容量だけでなく高電圧充電に対する寿命も重要であ

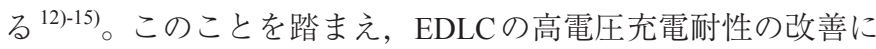
有効であることが知られる窒素ドープ処理 ${ }^{13)-16)}$ を賦活 KBに行 い，高容量・優れた高電圧充電耐性を併せ持つEDLC 電極主材 用カーボンブラックの開発を目指した。

\section{2. 実 験}

\section{1 試料調製}

本研究ではケッチェンブラックインターナショナル（現ライ オン・スペシャリティ・ケミカルズ）製のEC300JとEC600JD の2種類の KB を出発物質に用いた。EC600JDは高比表面積 グレードである。本研究ではこれ以降，前者の KBをKB300, 後者をKB600 と呼ぶ。Fig. 1に走査電子顕微鏡像を示した。 $\mathrm{KB} 300$ およびKB600 ともに数十 $\mathrm{nm}$ 程度のナノ粒子が連結して 

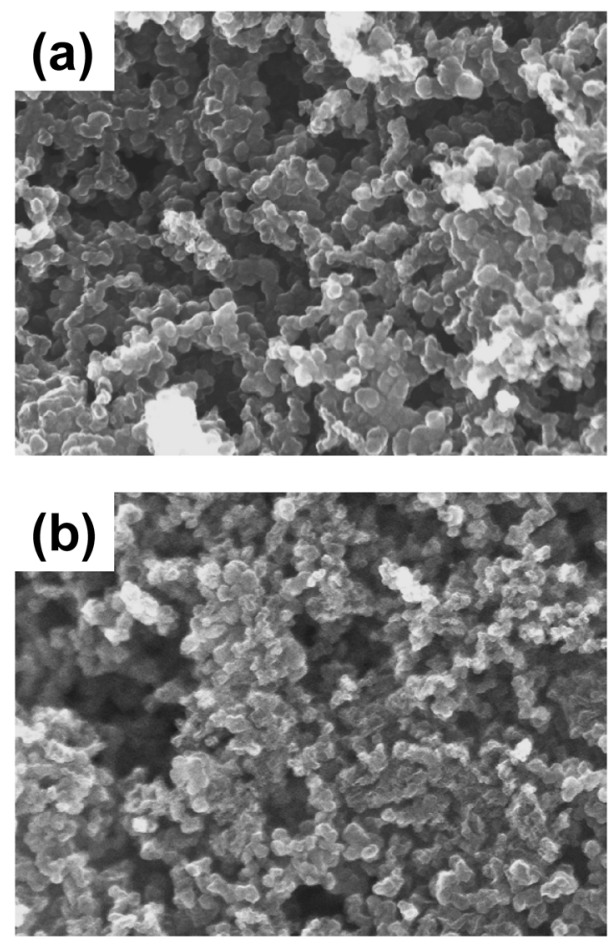

$100 \mathrm{~nm}$

Fig. 1 Scanning electron microscopic images of Ketjenblack, (a) EC300J, (b) EC600JD.

アグリゲートを形成していることが確認された。これは導電性 カーボンブラックに特徵的な構造である。

\subsubsection{KOH賦活}

$\mathrm{KB} 300$ あるいはKB600に対し重量比 5 倍の水酸化カリウム (試薬特級, 和光純薬工業製) を混ぜ合わせ, 高純度アルミナ ボートに入れた。これを横型管状炉において，窒素雲囲気下，

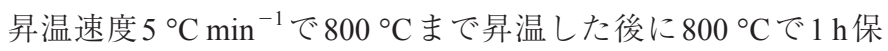
持することで $\mathrm{KOH}$ 賦活を行った。賦活後に蒸留水ならびに希 塩酸を用いて残留カリウム成分の除去を行った。その後, メ夕 ノールを用いた洗浄によってできるだけ水分を取り除き，最後 に熱真空乾燥を行うことで KOH賦活KB (K-KB300，K-KB600) を調製した。また，賦活によって増加した含酸素表面官能基 の低減を目的として高純度の窒素雲囲気( $99.999 \%)$ 下におい て $800{ }^{\circ} \mathrm{C} \cdot 1 \mathrm{~h}$ の熱処理を行うことで $\mathrm{KOH}$ 賦活-熱処理 KB (HKKB300, HK-KB600)を調製した。

\subsection{2 $\mathrm{CO}_{2}$ 賦活}

KB300あるいはKB600のKBをロータリーキルン炉におい て, 窒素雲囲気下, 昇温速度 $10^{\circ} \mathrm{C} \mathrm{min}^{-1}$ で $900{ }^{\circ} \mathrm{C}$ ま゙昇温し た後に純 $\mathrm{CO}_{2}(99.99 \%)$ に切り替え, $900{ }^{\circ} \mathrm{C} て ゙ 3 \mathrm{~h}$ 保持すること で $\mathrm{CO}_{2}$ 賦活を行った $\left(\mathrm{CO}_{2}-\mathrm{KB} 300, \mathrm{CO}_{2}-\mathrm{KB} 600\right)$ 。

\subsection{3 活性炭（比較試料）}

本研究では比較試料として, 水蒸気賦活によって調製された フェノール樹脂系活性炭素繊維ACF25（ACF1063-25, 日本力 イノール製）をメノウ乳鉢で粉砕した物（ACF25粉砕物）を用 いた。

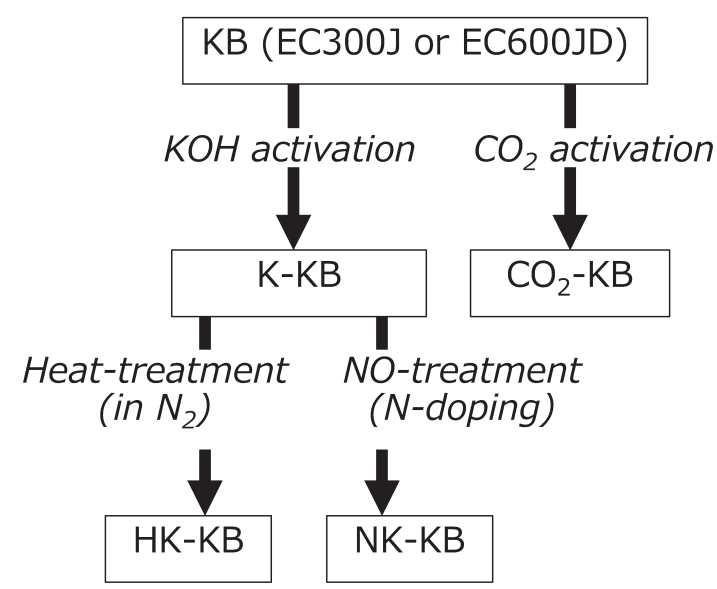

Fig. 2 Preparation process of each activated Ketjenblack.

\subsection{4 窒素ドープ}

本研究では，一酸化窒素 $(\mathrm{NO})$ ガス存在下での熱処理法に よって窒素ドープを行った。微量のNO存在下で熱処理を行う と以下の式により炭素表面に窒素が取り达まれる ${ }^{17) 。}$

$$
\mathrm{C}_{n}+\mathrm{NO} \rightarrow \mathrm{C}_{n-1}(\mathrm{~N})+\mathrm{CO}
$$

$\left(\mathrm{C}_{n}\right.$ : 表面炭素, $\mathrm{C}_{n-1}(\mathrm{~N})$ : 表面に窒素原子が取り达まれた炭 素)

前述のK-KB600をロータリーキルン炉において窒素䨌囲気下, 昇温速度 $5^{\circ} \mathrm{C} \mathrm{min}-1$ で $850{ }^{\circ} \mathrm{C}$ まで昇温した。その後，炉内に $8000 \mathrm{ppm}$ の $\mathrm{NO}$ を含む $\mathrm{He}$ ガスを流通し $850{ }^{\circ} \mathrm{C}$ で $1 \mathrm{~h}$ 反応させる ことによって窒素ドープを行った(NK-KB600)。

Fig. 2 に本研究で調製した各試料の調製手順をまとめた。

\section{2 キャラクタリゼーション}

\subsection{1 窒素吸脱着測定}

現マイクロトラック・ベル製BELSORP28SA-85を用いて $77 \mathrm{~K}$ に打ける窒素吸脱着測定を行い, 細孔構造を評価した。測定 に先立ち, 前処理として試料は $200{ }^{\circ} \mathrm{Cにて} 2 \mathrm{~h}$ の熱真空乾燥 を行った。吸着等温線の相対圧 $0 \sim 0.05$ の範囲から BET 比表面 積 $\left(S_{\mathrm{BET}}\right)$ を算出した。メソ孔容積 $\left(V_{\text {meso }}\right)$ とミクロ孔容積 $\left(V_{\text {micro }}\right)$ は吸着等温線をそれぞれDolimore-Heal (DH) 法 ${ }^{18)}$ ならびにDubinn-Radushkevich (DR) 法 ${ }^{19)}$ より求めた。なお, DH法では細孔 をシリンダー状としてみなして解析を行った。

\subsubsection{X線回折測定}

リガク製RINT2100V/PCを用いて粉末X線回折(X-Ray Diffraction, XRD) 測定を行い, 試料の結晶構造変化を調べた。X線 源には $\mathrm{CuK} \alpha$ 線 $(\lambda=0.154 \mathrm{~nm}, 32 \mathrm{kV}, 20 \mathrm{~mA})$ を用いた。測定範囲 は5 90 , 走査速度は $1^{\circ} \mathrm{min}^{-1}$ とした。

\subsection{3 昇温脱離スペクトル測定}

現マイクロトラック・ベル製全自動昇温脱離スペクトル測定 装置(TPD-1-AT)を用いて昇温脱離スペクトル(Temperature Programmed Desorption, TPD) 測定を行い, 含酸素表面官能基の分析 を行った。測定の前処理として，各試料を真空下で $200{ }^{\circ} \mathrm{C} \cdot 2 \mathrm{~h}$

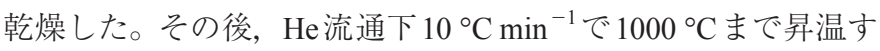
る間のガス成分 $\left(\mathrm{CO}\right.$ なら゙に $\left.\mathrm{CO}_{2}\right)$ を装置内蔵の四重極質量分 
析計によって記録した。 $\mathrm{CO}$ と $\mathrm{CO}_{2}$ の脱離量の定量については, シュウ酸カルシウム一水和物 $\left(\mathrm{CaC}_{2} \mathrm{O}_{4} \cdot \mathrm{H}_{2} \mathrm{O}\right.$, 和光純薬工業製 $)$ の $\mathrm{CO}$ および $\mathrm{CO}_{2}$ に関する TPDスペクトルから検量線を作成し て行った。

\subsection{4 元素分析ならびに $X$ 線光電子分光分析}

NK-KB600について，ジェイ・サイエンス・ラボ製炭素・ 水素・窒素同時定量装置(MICRO CORDER JM10)を用いて 燃焼法による元素分析を行った。また，NK-KB600について KRATOS製X線光電子分析装置(AXIS-NOVA)を用いてX線光 電子分光(X-ray Photoelectron Spectroscopy, XPS)測定を行い, ドープされた窒素の化学状態を調べた。XPSのX線源には $\mathrm{AlK} \alpha$ 線を用いて，各スペクトルのピーク面積と検出感度係数から $\mathrm{N}$, $\mathrm{C}$ の表面原子比 $(\mathrm{at} \%)$ を算出した。スペクトルの帯電補正は $\mathrm{C} 1 \mathrm{~s}$ の主ピークを $284.5 \mathrm{eV}$ とすることで行った。

\subsection{5 容量および高電圧充電耐性評価}

熱真空乾燥 $\left(200^{\circ} \mathrm{C} \cdot 2 \mathrm{~h}\right)$ させた各 $\mathrm{KB}$ 系試料 $30 \mathrm{mg}$ にポリテト ラフルオロエチレン系バインダー（PTFE6J，三井・デュポンフ ロロケミカル製）を所定の重量比（KB：バインダー = 90:10） で加え, 混練・成型することで電極ペレット（直径 $13 \mathrm{~mm}$ )を 作製した。また，比較試料に関しては，ACF25粉砕物 $30 \mathrm{mg}$, 導電補助剤としてのアセチレンブラック（デンカブラック，電 気化学工業製)，ならびにPTFE6Jを重量比 $85: 10: 5$ の割合で 混合し，KB系試料の場合と同様に電極ペレットとした。各電 極ペレットにアルミニウムメッシュを圧着して試験極とした。 なお，ペレットの厚みをマイクロメーターを用いて測定するこ とで各電極の体積を求め, 電極かさ密度を算出した。

各試験極は熱真空乾燥 $\left(200^{\circ} \mathrm{C} \cdot 2 \mathrm{~h}\right)$ 後にアルゴングローブボッ クス中（露点： $-70{ }^{\circ} \mathrm{C}$ 以下）に移した。本研究では，有機系電 解液として $1.0 \mathrm{~mol} \mathrm{dm}^{-3}$ のトリエチルメチルアンモニウムテトラ フルオロボレート $\left(\left(\mathrm{C}_{2} \mathrm{H}_{5}\right)_{3} \mathrm{CH}_{3} \mathrm{NBF}_{4}: \mathrm{TEMABF}_{4}\right)$ を含むプロピレン カーボネート溶液（富山薬品工業製）を用いた。試験極を電解 液に浸しグローブボックスのサイドボックスで $30 \mathrm{~min}$ 減圧脱気し た。その後に試験極を宝泉製アルミニウム製二極式セル（HS フ ラットセル）に組み込み, 電解液を約 $0.23 \mathrm{~cm}^{3}$ 注ぎ, 密閉した。

容量ならびに高電圧充電耐性の評価には北斗電工製自動充

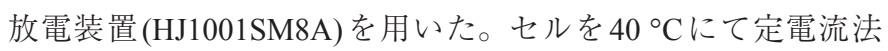
(0 2.5 V, 正負極での電流密度 : $\left.80 \mathrm{mAg}^{-1}\right)$ で 5 回の充放電サ イクル試験を行い, 安定した 5 回目の充放電曲線から容量（重 量比容量ならびに体積比容量）を求めた。重量比容量は以下の 式(2)を用いて算出した。

$$
C^{\mathrm{G}}=\frac{I \Delta t}{m \Delta E}
$$

$\left(C^{\mathrm{G}}\right.$ : 重量比容量 $\left[\mathrm{F} \mathrm{g}^{-1}\right], I$ : 電流值 $[\mathrm{A}], \Delta t$ : 時間変化 $[\mathrm{s}]$, $m:$ 正負極の主材合計重量 $[\mathrm{g}], \Delta E:$ 電圧変化 $[\mathrm{V}])$

体積比容量は，式(3)により求めた。
$C^{\mathrm{V}}=\frac{I \Delta t}{V \Delta E}$

$\left(C^{\mathrm{V}}\right.$ : 体積比容量 $\left[\mathrm{F} \mathrm{cm}^{-3}\right], I$ : 電流值 $[\mathrm{A}], \Delta t$ : 時間変化 $[\mathrm{s}]$,

$V:$ 正負極の合計体積 $\left[\mathrm{cm}^{3}\right], \Delta E:$ 電圧変化 $\left.[\mathrm{V}]\right)$

高電圧充電耐性については，フロート充電による耐久試験前 後の容量を比較して求めた容量維持率を指標とした。EDLCは 蓄電池とは異なり, 充放電サイクルに比べて一定の電圧で保 持を続けるフロート充電に弱いことが知られている ${ }^{20)}$ 。耐久試 験は， $70{ }^{\circ} \mathrm{C}$ 下において定電流法にて（0 3.0 Vあるいは $3.2 \mathrm{~V}$, 正負極での電流密度 : $\left.80 \mathrm{mAg}^{-1}\right)$ で充電放電サイクルを 5 回 行った後，所定電圧（3.0 Vあるいは $3.2 \mathrm{~V} ）$ を $100 \mathrm{~h}$ 印加し続け

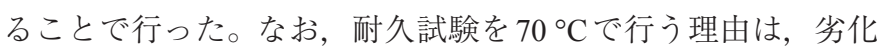
を加速させることで $100 \mathrm{~h}$ 程度のフロート充電でも劣化を顕在 化させること，ならびに車載用 EDLCなどの使用環境を考慮す ると比較的高温での特性が重要であること，の2点である。

\section{3. 結果と考察}

\section{1 賦活による細孔構造変化}

Fig. 3 に各試料の窒素吸脱着等温線を示した。ACF25の等温 線は，低相対圧部において急激な吸着量増加を示す $\mathrm{I}$ 型であり， ミクロ孔主体の多孔体であることが確認された。KBはメソ孔 性多孔体に典型的なヒステリシスループをもつIV型等温線を 示した。 $\mathrm{KOH}$ 賦活を行うと，KB300ならびにKB600の両方に おいて低相対圧部での吸着量が増加しており，ミクロ孔が発 達したことがわかる。また， $\mathrm{KOH}$ 賦活後に $800{ }^{\circ} \mathrm{C}$ の熱処理を 行っても等温線の変化は僅かであり，賦活によって生成した細 孔構造は熱的に安定であることがわかった。一方， $\mathrm{CO}_{2}$ 賦活を 行った場合，KB300，KB600ともにIV 型の特徵をそのまま残し ながら全相対圧領域で吸着量が増大するように等温線が変化し た。

Fig. 4 に各試料のDHプロットによるメソ孔領域の細孔径 分布曲線, Table 1 に吸着等温線から解析したBET比表面積 $\left(S_{\mathrm{BET}}\right)$, メソ孔容積 $\left(V_{\text {meso }}\right)$, ミクロ孔容積 $\left(V_{\text {micro }}\right)$, 賦活あるい は熱処理収率 $(\%)$ をまとめた。 $\mathrm{KOH}$ 賦活によって, KB300, KB600 ともにBET比表面積が増加した。前者ではミクロ孔容 積，メソ孔容積ともに増加するのに対して(K-KB300), 後者で はメソ孔容積は減少しミクロ孔容積が増加した $(\mathrm{K}-\mathrm{KB} 600)$ 。細 孔径分布曲線を見ると $\mathrm{KOH}$ 賦活によってミクロ孔に近い領域 では細孔容積が増加したが，細孔半径 $3 \mathrm{~nm}$ 以上のメソ孔が減 少している。したがって，KBへの $\mathrm{KOH}$ 賦活によってミクロ孔 の生成とともに既存のメソ細孔が収縮あるいは消失すると考 えられる。なお, Fig. 4, Table 1 から $\mathrm{KOH}$ 賦活後の窒素中での 熱処理は，細孔構造にほとんど影響を与えないことがわかる (HK-KB300, HK-KB600)。

$\mathrm{CO}_{2}$ 賦活によっても KBのBET 比表面積は増加したが，細孔 構造の変化の様子は $\mathrm{KOH}$ 賦活とは異なっていた(Table 1)。細 孔容積に関しては，両 KBともにミクロ孔に比べてメソ孔容積 が大きく増大しており，Fig. 4 の細孔径分布曲線からは特に細 

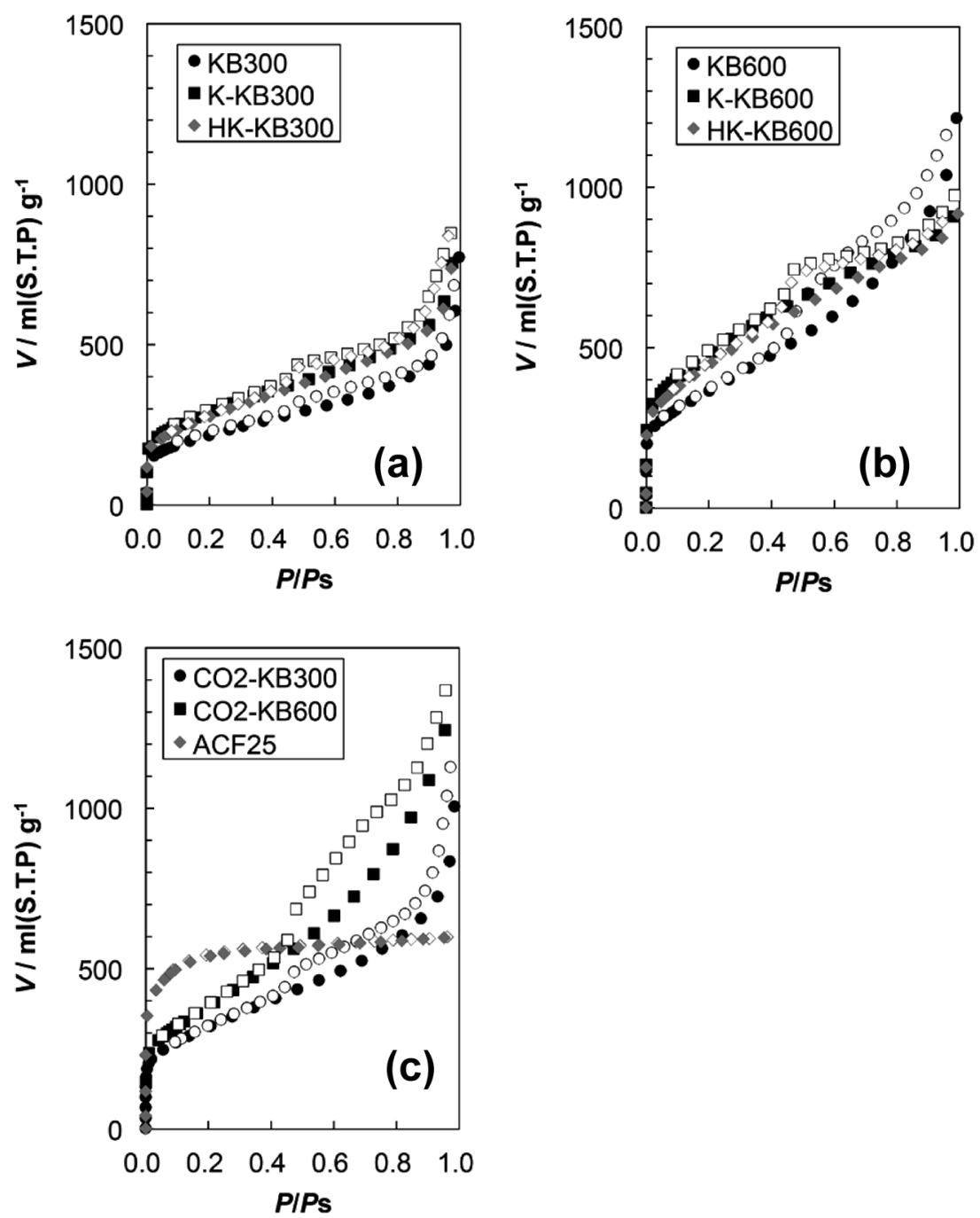

Fig. 3 Nitrogen adsorption/desorption isotherms (77 K) of Ketjenblack and their activated products, (a) KB300, KOH-activated KB300 (KKB300), or heat-treated K-KB300 (HK-KB300), (b) KB600, KOH-activated KB600 (K-KB600), or heat-treated K-KB600 (HK$\mathrm{KB} 600)$, and (c) $\mathrm{CO}_{2}$-activated $\mathrm{KB} 300\left(\mathrm{CO}_{2}-\mathrm{KB} 300\right), \mathrm{CO}_{2}$-activated $\mathrm{KB} 600\left(\mathrm{CO}_{2}-\mathrm{KB} 600\right)$, or activated carbon fiber (ACF25). Filled symbol: adsorption, Hollow symbol: desorption.

孔半径 2 $6 \mathrm{~nm}$ 付近のメソ孔が発達することがわかる。これら の結果より, $\mathrm{CO}_{2}$ 賦活の場合にはガス化が進んで細孔容積が増 加しても比表面積は増加しにくく, KB600では特にその傾向が 顕著であると言える。

以上のことから，KBは賦活方法によって細孔の発達の様子 が異なり，同程度の賦活収率であっても $\mathrm{KOH}$ 賦活ではミクロ 孔， $\mathrm{CO}_{2}$ 賦活ではメソ孔が特に発達しやすいことが明らかに なった。な扔，メソ孔が非常に発達した KBはキャパシタの レート特性を高めることが期待されるが，電極かさ密度が小さ いために実用上重要な体積比容量あるいは体積エネルギー密 度 ${ }^{21,221}$ が不十分であると予想される。したがって，これ以降 は体積比容量の改善が期待できる $\mathrm{KOH}$ 賦活物に絞ってキャラ クタリゼーションならびに容量評価を行った結果を述べる。

\section{2 賦活による結晶性変化}

Fig. 5 に各試料のXRD プロファイルを示した。全ての試料 に打いて結晶性の低い炭素に典型的な，ブロードな002抢よび 10 回折線が確認された。002回折線の幅に注目すると，ACF25
と比べてKB300の回折線の幅が明らかに鋭く，炭素網面の積 層方向の結晶性が比較的高いといえる。シェラーの式を用い て002回折線から結晶子サイズを求めると, ACF25, KB300, KB600 それぞれで約 $1.2,0.95,0.82 \mathrm{~nm}$ であった。興味深いこと に，賦活前後で回折プロファイルはほとんど変化していないこ とから，KOH賦活による結晶性の変化はほとんどないように 見える。一方, Table 1中の賦活収率は, 賦活によって無視で きない量の炭素がガス化消失することを示している。したがっ て，XRDプロファイルにほとんど反映されない結晶性の極め て低いマトリクスが $\mathrm{KOH}$ 賦活によってガス化されていると思 われる。

\section{3 昇温脱離スペクトル測定}

Fig. 6 に各試料の $\mathrm{CO}$ 㧍よび $\mathrm{CO}_{2}$ 脱離スペクトルを，Table 2 にスペクトルから算出した $\mathrm{CO}$ 扩よび $\mathrm{CO}_{2}$ 脱離量を示した。 $\mathrm{KB}$ 系試料について全般的に $\mathrm{CO}$ 扮よび $\mathrm{CO}_{2}$ 脱離量が $\mathrm{ACF} 25$ より も非常に小さかった。賦活前，KOH賦活後ともに，KB600系 試料の脱離量はKB300系試料と比べて大きかった。これは, 

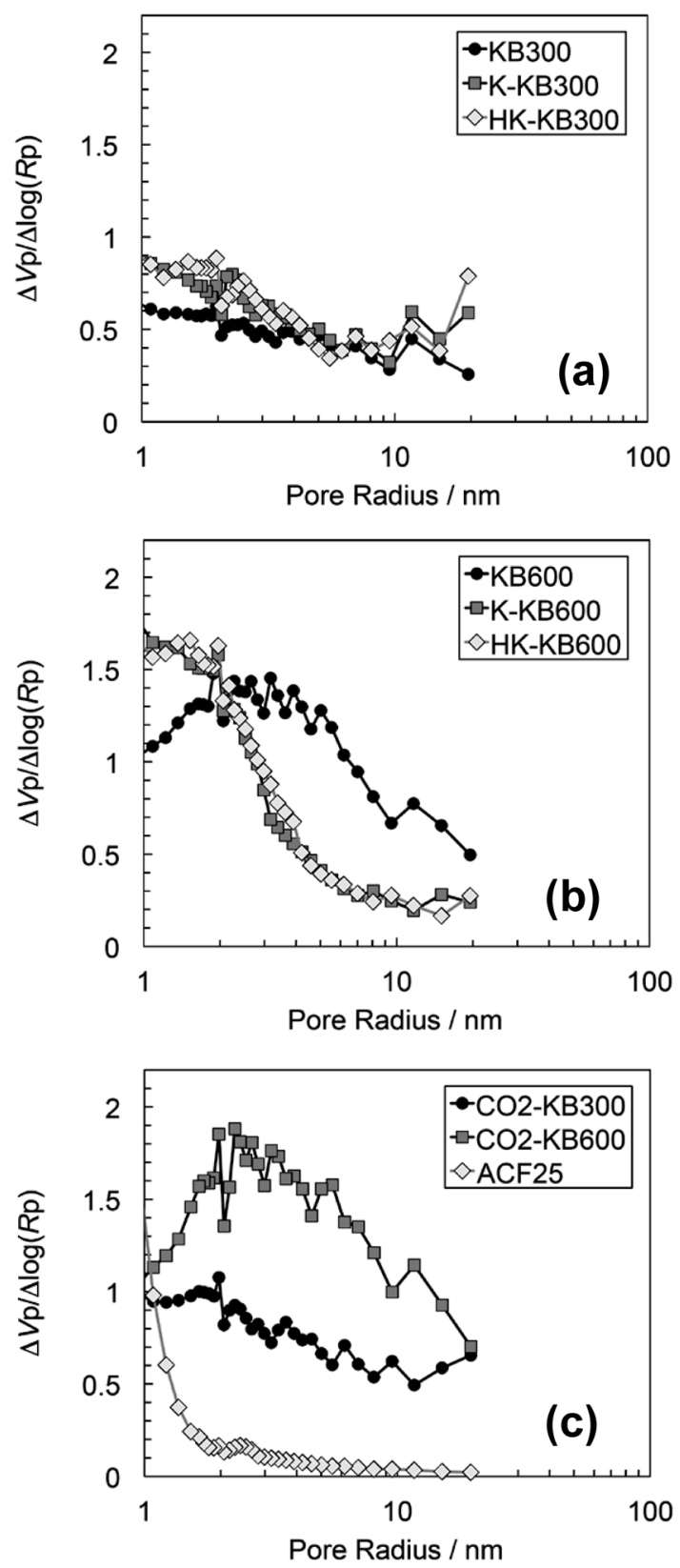

Fig. 4 Pore size distribution curves calculated from adsorption isotherms by DH method for Ketjenblack and their activated products, (a) KB300, K-KB300, or HK-KB300, (b) KB600, $\mathrm{K}-\mathrm{KB} 600$, or $\mathrm{HK}-\mathrm{KB} 600$, and (c) $\mathrm{CO}_{2}-\mathrm{KB} 300, \mathrm{CO}_{2}-\mathrm{KB} 600$, or ACF25.

KB600系試料の高い比表面積によるものと考えられる。KBの 種類に依らず $\mathrm{KOH}$ 賦活によって $\mathrm{CO}$ および $\mathrm{CO}_{2}$ 脱離量が増加 するが，熱処理を行うことで $\mathrm{CO}$ および $\mathrm{CO}_{2}$ 脱離量は賦活前の レベル近くまで減少した。

文献 ${ }^{23)-25)}$ から 600 900 ${ }^{\circ} \mathrm{C}$ 付近で脱離するCOは, 主にフェ ノール性水酸基，カルボニル基，エーテル基に帰属され，一方， 200 $600{ }^{\circ} \mathrm{C}$ 付近での $\mathrm{CO}_{2}$ の脱離はカルボキシ基やラクトン基の 分解に帰属される。このことから, $\mathrm{KOH}$ 賦活によって増加し たフェノール性水酸基，カルボニル基，エーテル基などの含酸 素官能基は，その後の窒素䨌囲気中での熱処理によって多くが 除去されると言える。一般的には，EDLC用の活性炭電極では，

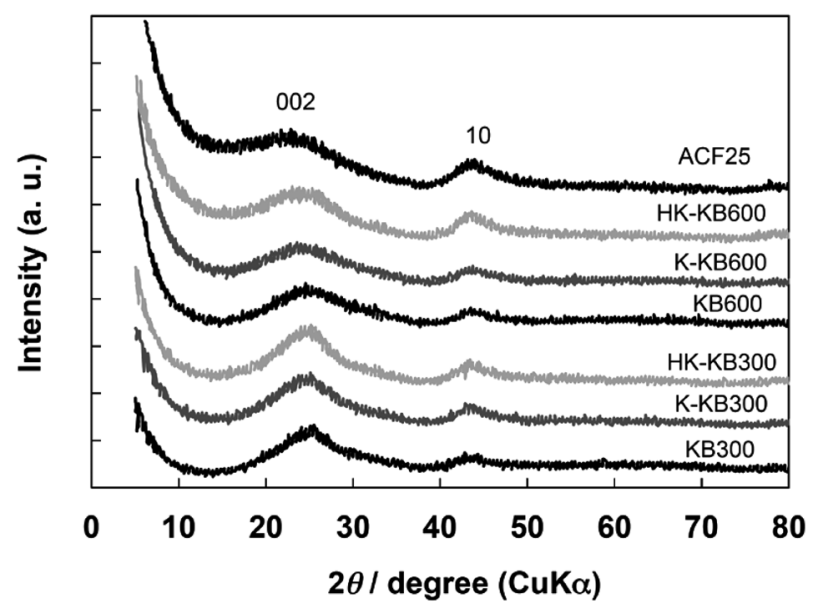

Fig. 5 X-ray diffraction profiles $(\mathrm{CuK} \alpha)$ of $\mathrm{KB} 300, \mathrm{~K}-\mathrm{KB} 300$, HKKB300, KB600, K-KB600, HK-KB600, and ACF25.

Table 1 Pore structure and yield.

\begin{tabular}{lccccc}
\hline \multicolumn{1}{c}{ Sample } & Process & $\begin{array}{c}S_{\mathrm{BET}} \\
{\left[\mathrm{m}^{2} \mathrm{~g}^{-1}\right]}\end{array}$ & $\begin{array}{c}V_{\text {meso }} \\
{\left[\mathrm{mL} \mathrm{g}^{-1}\right]}\end{array}$ & $\begin{array}{c}V_{\text {micro }} \\
{\left[\mathrm{mL} \mathrm{g}^{-1}\right]}\end{array}$ & $\begin{array}{c}\text { Yield } \\
{[\%]}\end{array}$ \\
\hline $\mathrm{KB} 300$ & Pristine & 700 & 0.67 & 0.28 & - \\
$\mathrm{K}-\mathrm{KB} 300$ & $\mathrm{KOH}$ & 930 & 0.89 & 0.39 & 71 \\
$\mathrm{HK}-\mathrm{KB} 300$ & $\mathrm{KOH} / \mathrm{HT}$ & 750 & 0.90 & 0.35 & 96 \\
$\mathrm{CO}_{2}-\mathrm{KB} 300$ & $\mathrm{CO}_{2}$ & 1020 & 1.10 & 0.43 & 64 \\
$\mathrm{~KB} 60$ & Pristine & 1150 & 1.51 & 0.46 & - \\
$\mathrm{K}-\mathrm{KB} 600$ & $\mathrm{KOH}$ & 1480 & 1.17 & 0.67 & 69 \\
$\mathrm{HK}-\mathrm{KB} 600$ & $\mathrm{KOH} / \mathrm{HT}$ & 1370 & 1.17 & 0.58 & 97 \\
$\mathrm{CO}_{2}-\mathrm{KB} 600$ & $\mathrm{CO}_{2}$ & 1260 & 1.88 & 0.55 & 74 \\
$\mathrm{ACF} 25$ & - & 1870 & 0.31 & 0.73 & - \\
\hline
\end{tabular}

$\mathrm{KOH}: \mathrm{KOH}$ activation, $\mathrm{CO}_{2}$ : $\mathrm{CO}_{2}$ activation $\mathrm{HT}$ : heat-treatment at $800{ }^{\circ} \mathrm{C}$ in nitrogen, $S_{\mathrm{BET}}$ : BET specific surface area, $V_{\text {meso }}$ : mesopore volume calculated by $\mathrm{DH}$ method, $V_{\text {micro }}$ : micropore volume calculated by DR method.

含酸素表面官能基の存在が自己放電・寿命特性を低下させるこ

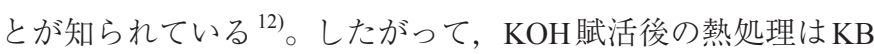
を電極主材とするキャパシタの信頼性を高めると期待できる。

\section{4 充放電容量測定および高電圧耐久試験}

Fig. 7 に3.0 Vのフロート耐久試験前後の充放電曲線を示し た。全ての試料が容量性を示す直線的な軌跡を描き，典型的な キャパシタ電極としての特性を示した。耐久試験後も各試料は キャパシ夕的な充放電曲線を示したが，充放電に要する時間 が短くなった。これは耐久試験により容量が低下したことを表 す。特にKOH賦活した KBについては，耐久試験による充放 電曲線の変化が大きく，劣化が進んでいることがわかる。

Table 3 に各試料の電極かさ密度, 耐久試験前の容量（初期 容量)，ならびに耐久試験後の容量維持率を示した。 $\mathrm{KOH}$ 賦活 前の KBは，ACF $25 に$ 比べて電極かさ密度が低い。これは，KB はメソ孔主体の多孔体であるためである。初期重量比容量に 関してKB600はKB300に比べて高く，このことは前者の高い 比表面積によるものである。しかし，KB600の容量はACF25 に比べると低く，さらには電極かさ密度も低いため，実用に重 要な体積比容量に関して KBは活性炭に比べて見劣りする。一 

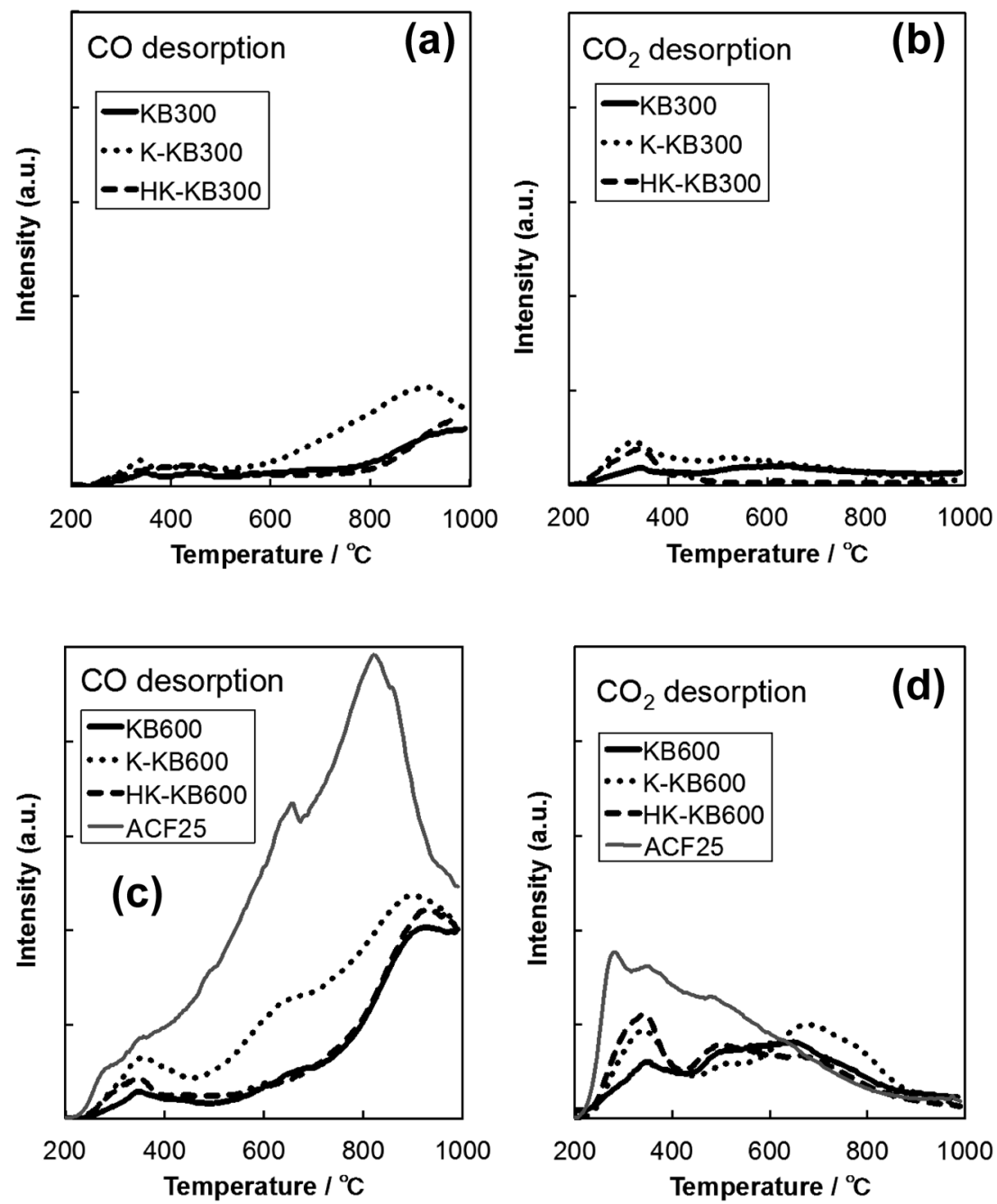

Fig. 6 Temperature programed $\mathrm{CO} / \mathrm{CO}_{2}$ desorption curves of (a, b) KB300, K-KB300, or HK-KB300, (c, d) KB600, K-KB600, HK-KB600, or ACF25.

Table 2 Amount of desorbed $\mathrm{CO}$ and $\mathrm{CO}_{2}$.

\begin{tabular}{lcc}
\hline \multicolumn{1}{c}{ Sample } & $A_{\mathrm{CO}}\left[\mu \mathrm{mol} \mathrm{g}^{-1}\right]$ & $A_{\mathrm{CO} 2}\left[\mu \mathrm{mol} \mathrm{g}^{-1}\right]$ \\
\hline KB300 & 320 & 100 \\
K-KB300 & 690 & 150 \\
HK-KB300 & 310 & 60 \\
KB600 & 1000 & 370 \\
K-KB600 & 1800 & 430 \\
HK-KB600 & 1200 & 400 \\
ACF25 & 3700 & 640 \\
\hline
\end{tabular}

TPD analysis was conducted by heating $\left(200 \sim 1000{ }^{\circ} \mathrm{C}\right)$ in He atmosphere, $A_{\mathrm{CO}}$ : amount of desorbed $\mathrm{CO}$, detected by TPD analysis, $A_{\mathrm{CO} 2}$ : amount of desorbed $\mathrm{CO}_{2}$, detected by TPD analysis.

方，耐久試験後の容量維持率に関しては，KB300 はACF25に 比べて高く，KB600もACF25 と同等の值を示した。

$\mathrm{KOH}$ 賦活を施したKBは，KB300ならびにKB600ともに比表 面積の増加に伴い容量が増加した。同時に電極かさ密度が向上 しているため体積比容量も改善され, 特にK-KB600はACF25 に迫る体積比容量を有するようになった。電極かさ密度の向上 は，KOH賦活によってメソ孔容積が減少し，代わりにミクロ 孔容積が増加したことで説明できる。なお，耐久試験後の容量
維持率に関してはKOH賦活によって低下したが，窒素䨌囲気 中での熱処理によって容量そのものをあまり変化させずに容 量維持率を改善できた。K-KB600の熱処理物 (HK-KB600)は, ACF25に迫る体積比容量と非常に高い容量維持率(99\%)を併也 もつ電極主材となった。したがって，800 ${ }^{\circ} \mathrm{C}$ 程度の熱処理を施 せば，細孔収縮に伴う容量低下がなく，かつ高電圧充電耐性の 低下の原因となる含酸素表面官能基を低減できると言える。

\section{5 窒素ドープ効果}

Fig. 8 にK-KB600の NO 処理物 (NK-KB600)のN 1s XPS スペク トルを示した。スペクトルは窒素表面官能基に関する文献 ${ }^{26)}$ に基づき波形分離を行った。ドープ窒素は主にピリジン型，ピ ロール型，四級型の状態で存在することがわかった。Table 4 にはXPS 分析から算出したNK-KB600の窒素官能基存在比な らびに窒素炭素原子比 $\left(\mathrm{N} / \mathrm{C}_{\mathrm{XPS}}\right)$ をまとめた。窒素炭素原子比 に関しては燃焼法による元素分析から求めた窒素炭素原子比 $\left(\mathrm{N} / \mathrm{C}_{\mathrm{com}}\right)$ も示した。 $\mathrm{NO}$ 処理によって原子比で約 1 at $\%$ の窒素が ドープされたことがわかった。また，N/C XPS と N/C 致していることにより，窒素原子は表面だけではなく試料全体 にドープされたことが示唆された。これらの結果はNO処理に 

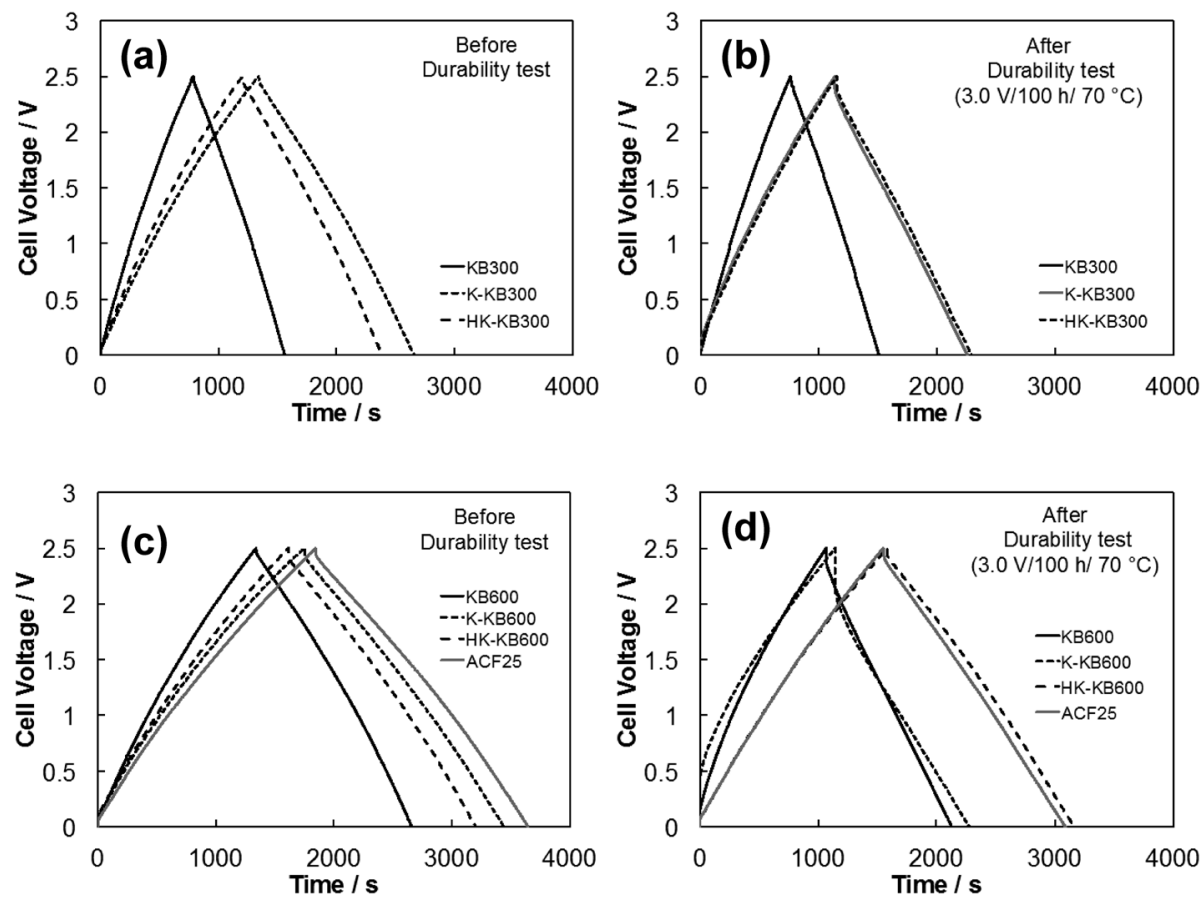

Fig. 7 Charge-discharge curves (current density: $80 \mathrm{mAg}^{-1}$ for positive or negative electrode, $40^{\circ} \mathrm{C}$ ) of two-electrode cells before and after float charging durability test $\left(3.0 \mathrm{~V}, 100 \mathrm{~h}, 70^{\circ} \mathrm{C}\right)$. (a, b) KB300, K-KB300, or HK-KB300, (c, d) KB600, K-KB600, HK-KB600, or ACF25.

Table 3 Electrode bulk densities and capacitance properties for durability test $(3.0 \mathrm{~V})$.

\begin{tabular}{lcccc}
\hline \multicolumn{1}{c}{ Sample } & $\rho\left[\mathrm{g} \mathrm{cm}^{-3}\right]$ & $C_{0}{ }^{\mathrm{G}}\left[\mathrm{F} \mathrm{g}^{-1}\right]$ & $C_{0}{ }^{\mathrm{V}}\left[\mathrm{F} \mathrm{cm}^{-3}\right]$ & $C_{\mathrm{d}} / C_{0}[\%]$ \\
\hline KB300 & 0.37 & 12 & 4.9 & 97 \\
K-KB300 & 0.54 & 20 & 12 & 84 \\
HK-KB300 & 0.46 & 19 & 9.7 & 97 \\
KB600 & 0.36 & 21 & 8.4 & 86 \\
K-KB600 & 0.45 & 27 & 14 & 67 \\
HK-KB600 & 0.45 & 25 & 13 & 99 \\
ACF25 & 0.52 & 28 & 17 & 86 \\
\hline
\end{tabular}

$\rho$ : electrode bulk density, $C_{0}{ }^{\mathrm{G}}$ : initial gravimetric capacitance, $C_{0}{ }^{\mathrm{V}}$ : initial volumetric capacitance, $C_{\mathrm{d}} / C_{0}$ : capacitance retention (ratio of capacitance after durability test/initial capacitance) by the durability test (floating condition: $3.0 \mathrm{~V}, 100 \mathrm{~h}, 70^{\circ} \mathrm{C}$ ). Capacitance was evaluated by constant current condition $\left(0 \sim 2.5 \mathrm{~V}, 80 \mathrm{~mA} \mathrm{~g}^{-1}\right.$ for positive or negative electrode, $\left.40^{\circ} \mathrm{C}\right)$ with two-electrode cell.

Table 4 Atomic concentration of elemental nitrogen and N-functionalities.

\begin{tabular}{|c|c|c|c|c|c|c|}
\hline Sample & $\mathrm{N} / \mathrm{C}_{\text {com }}$ & $\mathrm{N} / \mathrm{C}_{\mathrm{XPS}}$ & N-6 [\%] & N-5 [\%] & $\mathrm{N}-\mathrm{Q}[\%]$ & $\mathrm{N}-\mathrm{X}[\%]$ \\
\hline NK-KB600 & 0.009 & 0.008 & 52 & 21 & 19 & 7 \\
\hline
\end{tabular}

$\mathrm{N} / \mathrm{C}_{\text {com }}$ : atomic ratio of nitrogen to carbon, evaluated by combution elemental analysis, $\mathrm{N} / \mathrm{C}_{\mathrm{XPS}}$ : atomic ratio of nitrogen to carbon, evaluated by XPS analysis, N-6: pylidine-like, N-5: pyrrole or pyridone-like, N-Q: quaternary-like, $\mathrm{N}-\mathrm{X}$ : oxide-like nitrogen functionality.

よって窒素ドープした活性炭の場合と一致している ${ }^{27)}$ 。

Fig. 9 にNK-KB6000の窒素吸脱着等温線を示した（比較のた めにK-KB600のデータも併記した)。また，Table 5 に等温線か ら解析した細孔構造パラメーター，ドープ収率，ならびに電極 かさ密度を示した。NO処理による窒素ドープ後も窒素吸脱着等

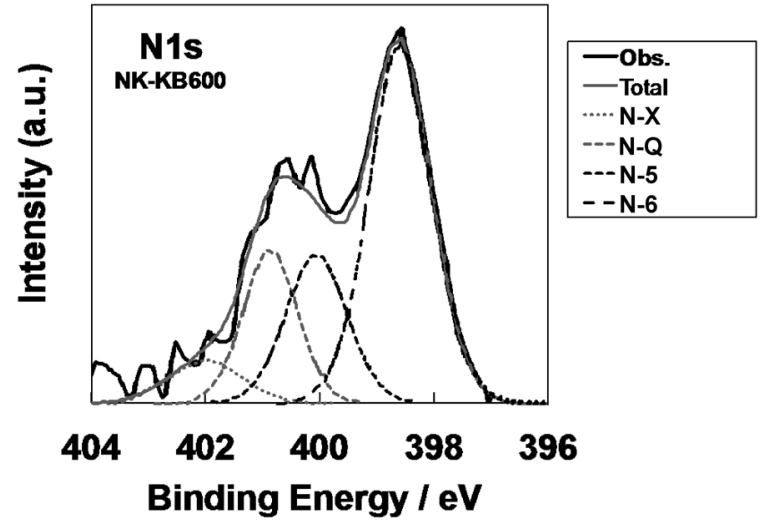

Fig. 8 N1s X-ray photoelectron spectrum (XPS) of NO-treated K-KB600 (NK-KB600). Obs.: observed spectrum, Total: total deconvoluted curves, N-6: deconvoluted curve of pylidine-like nitrogen functionality, N-5: pyrrole or pyridonelike, N-Q: quaternary-like, N-X: oxide-like.

温線に大きな変化はなく，電極かさ密度も処理前と一致してい た。比表面積，細孔容積の観点からも NO処理後も細孔構造は ほぼ維持されると言える。ただし，NK-KB600はHK-KB600 と 比べればやや細孔が発達している。これは，収率から判断して $\mathrm{NO}$ 処理中に僅かながらガス化が進行していることを示唆して いる。NO処理では，式(1)のドープ反応以外に窒素原子が取り 达まれず脱離するプロセスが一部並行して進むと考えられる。

Fig. 10 に各電極の $3.2 \mathrm{~V}$ でのフロート耐久試験前後の充放電 曲線を示した。ここでの耐久試験は前項と比べるとフロート電 圧が $0.2 \mathrm{~V}$ 高く，より過酷な条件で行われている。実際にFig. 7 と比べると Fig. 10 における耐久試験後の充放電曲線の変化は 大きかった。特にACF25の場合には充放電曲線の傾きがかな 


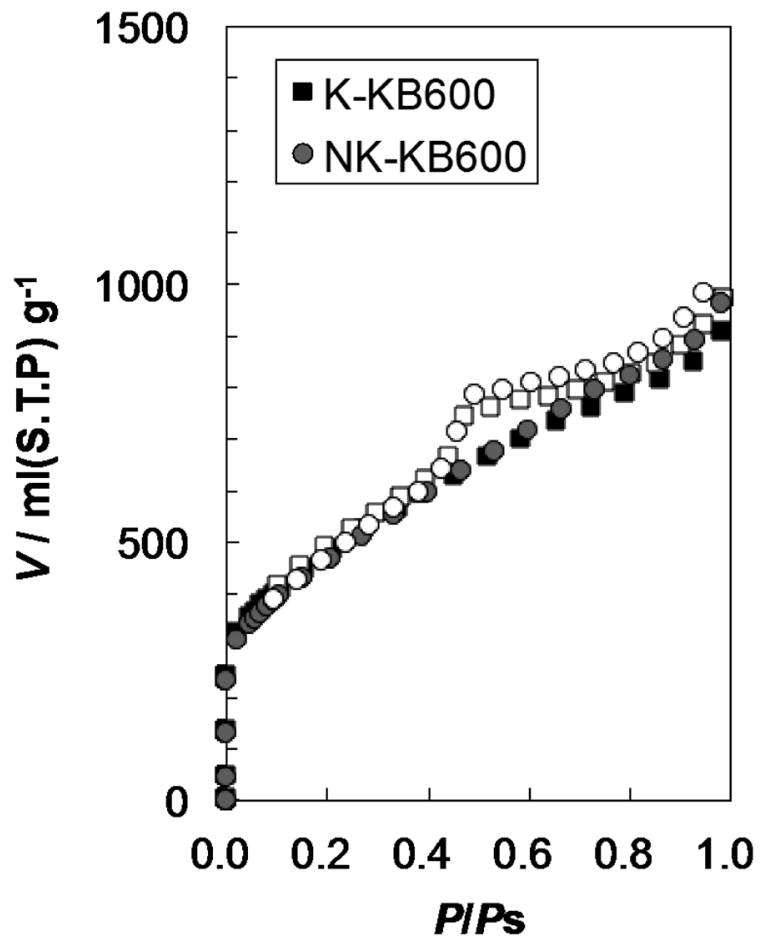

Fig. 9 Nitrogen adsorption/desorption isotherms $(77 \mathrm{~K})$ of K-KB600 and NK-KB600. Filled symbol: adsorption, Hollow symbol: desorption.

Table 5 Pore structure, yield, and electrode bulk density of Ndoped K-KB600.

\begin{tabular}{cccccc}
\hline Sample & $\begin{array}{c}S_{\mathrm{BET}} \\
{\left[\mathrm{m}^{2} \mathrm{~g}^{-1}\right]}\end{array}$ & $\begin{array}{c}V_{\text {meso }} \\
{\left[\mathrm{mL} \mathrm{g}^{-1}\right]}\end{array}$ & $\begin{array}{c}V_{\text {micro }} \\
{\left[\mathrm{mL} \mathrm{g}^{-1}\right]}\end{array}$ & $\begin{array}{c}\text { Yield } \\
{[\%]}\end{array}$ & $\begin{array}{c}\rho \\
{\left[\mathrm{g} \mathrm{cm}^{-3}\right]}\end{array}$ \\
\hline NK-KB600 & 1430 & 1.28 & 0.60 & 90 & 0.45 \\
\hline
\end{tabular}

$S_{\mathrm{BET}}$ : BET specific surface area, $V_{\text {meso }}$ : mesopore volume calculated by $\mathrm{DH}$ method, $V_{\text {micro }}$ : micropore volume calculated by DR method, $\rho$ : electrode bulk density.

り急になっており, 劣化が大きく進んでいた（容量維持率は 66\%）。Fig. 10から算出した耐久試験前の容量（初期容量），な らびに耐久試験後の容量維持率を Table 6にまとめた。初期容 量については窒素ドープの影響はほとんどないと言える。一 方，容量維持率に関してはNK-KB600の場合には88\%であり, K-KB600ならびにHK-KB600に比べて大きく改善されていた。 したがって，NO処理による窒素ドープは $\mathrm{KB} の \mathrm{KOH}$ 賦活物に 対して有効であることが明らかになった。

\section{6 高電圧充電耐性について}

KB を電極主材として用いたEDLCの特徴は，活性炭と比較 して互角に迫る容量を有するだけでなく，高電圧充電耐性が 比較的優れていることにあると言える。例えば， $3 \mathrm{~V}$ のフロー 卜耐久試験でKB300は非常に高い容量維持率を示した(Table 3, 97\%)。一般的には，有機系電解液を用いたEDLCに $3 \mathrm{~V}$ 以上の 高電圧を印可すると, 電極電解液面において電気分解が生じて 電極が劣化する ${ }^{28-31)}$ 。電気分解は分解生成物の析出によって 細孔を閉塞させ，さらにはバインダーの破壊だけでなく，絶縁 性分解物の析出によって電極内活物質粒子同士の接触抵抗の増
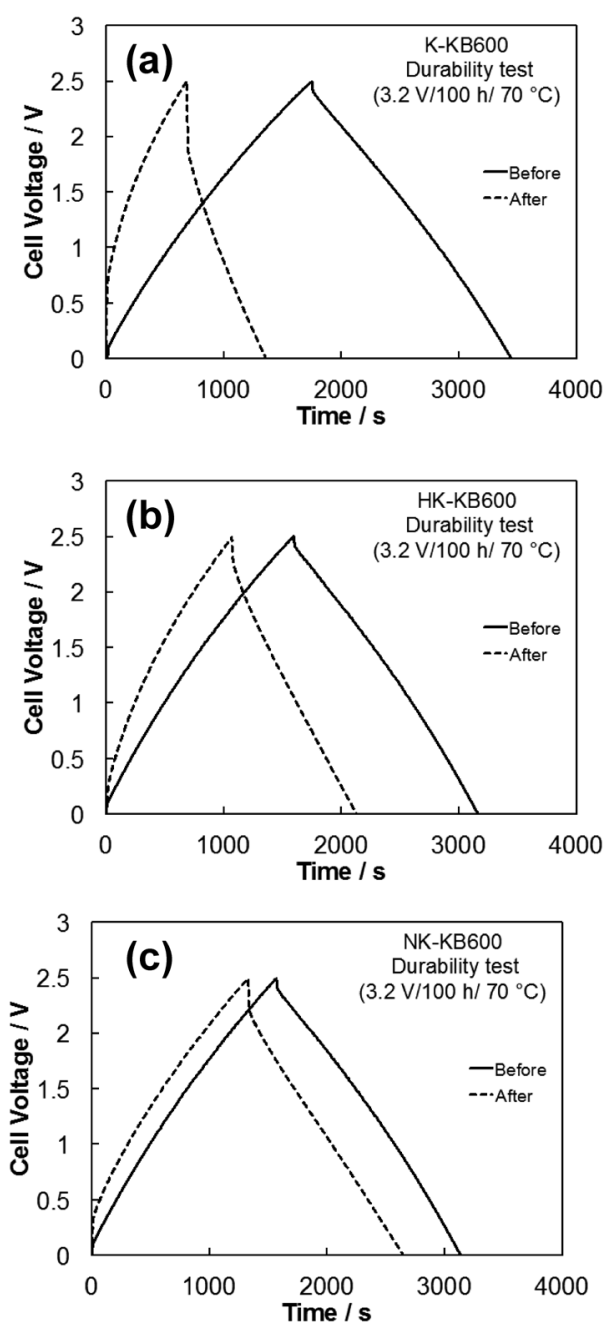

Fig. 10 Charge-discharge curves (current density: $80 \mathrm{mAg}^{-1}$ for positive or negative electrode, $40^{\circ} \mathrm{C}$ ) of two-electrode cells before and after float charging durability test $(3.2 \mathrm{~V}, 100 \mathrm{~h}$, $70{ }^{\circ} \mathrm{C}$ ), (a) K-KB300, (b) HK-KB600, (c) NK-KB600.

Table 6 Capacitance properties for durability test (3.2 V).

\begin{tabular}{lcccc}
\multicolumn{1}{c}{ Sample } & $C_{0}{ }^{\mathrm{G}}\left[\mathrm{F} \mathrm{g}^{-1}\right]$ & $C_{0}{ }^{\mathrm{V}}\left[\mathrm{F} \mathrm{cm}^{-3}\right]$ & $C_{\mathrm{d}} / C_{0}[\%]$ & Eff. [\%] \\
\hline KB600 & 21 & 8.4 & 73 & 79 \\
K-KB600 & 27 & 14 & 40 & 78 \\
HK-KB600 & 25 & 13 & 68 & 82 \\
NK-KB600 & 24 & 13 & 88 & 89 \\
ACF25 & 28 & 17 & 66 & 73 \\
\hline
\end{tabular}

$C_{0}{ }^{\mathrm{G}}$ : initial gravimetric capacitance, $C_{0}{ }^{\mathrm{V}}$ : initial volumetric capacitance, $C_{\mathrm{d}} / C_{0}$ : capacitance retention (ratio of capacitance after durability test/ initial capacitance) by the durability test (floating condition: $3.2 \mathrm{~V}, 100 \mathrm{~h}$, $\left.70{ }^{\circ} \mathrm{C}\right)$. Capacitance was evaluated by constant current condition $(0 \sim 2.5 \mathrm{~V}$, $80 \mathrm{~mA} \mathrm{~g}^{-1}$ for positive or negative electrode, $40^{\circ} \mathrm{C}$ ) with two-electrode cell. Eff.: coulombic efficiency for the first charge-discharge cycle $\left(0 \sim 3.2 \mathrm{~V}, 80 \mathrm{~mA} \mathrm{~g}^{-1}\right.$ for positive or negative electrode, $\left.70^{\circ} \mathrm{C}\right)$.

加も引き起こすことになり，結果的に容量が減少する。KBの 優れた耐性は，メソ孔が発達していることによって分解生成物 による細孔の閉塞がされにくいことが一因であると思われる。

Table 6にはKB600ならびにその各種処理物に関して上限電 圧 $3.2 \mathrm{~V}$ の場合の初回充放電サイクルに扔けるクーロン効率に ついても示した。クーロン効率が $100 \%$ を大幅に下回るのは, 
充電中において電気分解に使われた電気量が無視できないほど 大きいことを意味する。 $\mathrm{KOH}$ 賦活前後では初回充放電サイク ルのクーロン効率には大きな違いはないが，耐久試験前後の 容量維持率は未賦活品の方が高い。このことは, 電気分解の程 度が同等であっても，発達したメソ孔の存在が分解生成物によ る細孔閉塞の影響を弱め，高電圧充電耐性を高めることを示唆 している。一方，賦活後に熱処理や窒素ドープを施すとクー ロン効率が改善された。KB600の各種処理物にはほとんど細孔 構造の違いがないことを考慮すると，この結果は熱処理や窒素 ドープ処理が高電圧充電に伴う電気分解を抑制する効果がある ことを示している。特に窒素ドープはその効果が顕著であると 言え，この結果は耐久試験による容量維持率の傾向とも一致す る。筆者らは窒素ドープによって生成した窒素表面官能基が電 気化学的に安定であることが窒素ドープによる効果において重 要であると考えている26)

\section{4. 結 論}

本研究では，2種類のケッチェンブラックに賦活を施し， EDLCの電極主材としての特性を評価した。ケッチェンブラック は $\mathrm{KOH}$ 賦活ならびに $\mathrm{CO}_{2}$ 賦活によって高比表面積化されたが， 体積比容量という観点からは $\mathrm{KOH}$ 賦活が望ましいことがわかっ た。KOH賦活ケッチェンブラックを電極主材に用いたEDLCは, 賦活前に比べて体積比容量が向上したが，高電圧充電耐性は低 下した。KOH賦活ケッチェンブラックに対して不活性雲囲気下 での熱処理，あるいはNO処理による窒素ドープを施すことで， 容量をほとんど低下させずに高電圧充電耐性を高めることがで きた。特に高比表面積グレードのケッチェンブラック (EC600JD) に $\mathrm{KOH}$ 賦活と $\mathrm{NO}$ 処理による窒素ドープを組み合わせることで, 活性炭に迫る高容量かつ優れた高電圧充電耐性を有するEDLC 用電極主材が調製できることが明らかになった。

\section{謝 辞}

本研究の一部は, JSPS 科研費「17H03123」, 群馬大学元素機 能科学プロジェクト, 同大学大学院理工学府分子科学部門萌芽 研究助成の援助を受けた。関係各位に感謝申し上げる。また， ケッチェンブラックをご提供いただいたケッチェンブラックイ ンターナショナル株式会社（現 ライオン・スペシャリティ・ ケミカルズ株式会社）に厚く御礼申し上げる。

\section{文 献}

1) S. Maeno, TANSO 2006 [No. 222] 140-146 [in Japanese].

2) H. Hisashi, Nihon Insatsu Gakkaishi (J. Print. Sci. Technol.) 44 (2007) 133-143 [in Japanese].
3) M. Inagaki and F. Kang, Material Science and Engineering of Carbon: Fundamentals Second ed. (2014) pp. 38-40, Elsevier, Amsterdam.

4) K. Hiratsuka, Y. Sanada, T. Morimoto and K. Kurihara, Denki Kagaku (Electrochem.) 59 (1991) 607-613 [in Japanese].

5) D. Tashima, K. Kurosawatsu, Y.-M. Sung, M. Otsubo and C. Honda, Electrochem 73 (2005) 900-902 [in Japanese].

6) D. Tashima, H. Yoshitama, M. Otsubo, S. Maeno and Y. Nagasawa, Electrochim. Acta 56 (2011) 8941-8946.

7) F. Beck, M. Dolata, E. Grivei and N. Probst, J. Appl. Electrochem. 31 (2001) 845-853.

8) S. Shiraishi, N. Nishina, A. Oya and R. Hagiwara, Electrochem. 73 (2005) 593-596.

9) 白石壮志，最新カーボンブラック技術大全集(2005) pp. 560-575, 技術情報協会.

10) N. V. Maltseva, V. A. Golovin, Y. O. Chikunova and E. N. Gribov, Russ. J. Electrochem. 54 (2018) 489-496.

11) G. Kühner and M. Voll, Carbon Black: Science and Technology, Second Edition (J.-B. Donnet, R. C. Bansal and M.-J. Wang, eds.) (1993) pp. 2-66, CRC Press, Boca Raton.

12) S. Shiraishi, TANSO 2007 [No. 228] 195-199 [in Japanese].

13）矢島弘行，大容量キャパシタ—電気を無䭾なくためて賢く使う一 （直井勝彦，堀 洋一，編著）(2019) pp.53-78，コロナ社.

14) S. Shiraishi, Ceramics Japan 50 (2015) 633-636 [in Japanese].

15) S. Shiraishi, Bol. Grupo Español Carbón 28 (2013) 18-24.

16) 大谷朝男, 白石壮志，登之内 敬，安藤保雄，京谷 隆，特許第 4943828 号 (2012).

17) T. Suzuki, T. Kyotani and A. Tomita, Ind. Eng. Chem. Res. 33 (1994) 2840-2845.

18) M. M. Dubinin and H. F. Stoeckli, J. Colloid Interface Sci. 75 (1980) 3442.

19) M. El-Merraoui, H. Tamai, H. Yasuda, T. Kanata, J. Mondori, K. Nadai and K. Kaneko, Carbon 36 (1998) 1769-1776.

20) D. Weingarth, A. Foelske-Schmitz and R. Kötz, J. Power Sources 225 (2013) 84-88.

21) T. Morimoto, TANSO 214 (2004) 202-209 [in Japanese].

22) Y. Gogotsi and P. Simon, Science 334 (2011) 917-918.

23) K. Yamabe and H. Takahashi, TANSO 1980 [No. 102] 106-115 [in Japanese].

24) J. L. Figueiredo, M. F. R. Pereira, M. M. A. Freitas and J. J. M. Órfão, Carbon 37 (1999) 1379-1389.

25) H. Takagi, TANSO 2009 [No. 237] 67-71 [in Japanese].

26) E. Raymundo-Piñero, D. Cazorla-Amorós and A. Linares-Solano, Carbon 41 (2003) 1925-1932.

27) S. Shiraishi, Key Eng. Mater. 497 (2012) 80-86.

28) P. Azaïs, L. Duclaux, P. Florian, D. Massiot, M. A. Lillo-Rodenas, A. Linares-Solano, J. P. Peres, C. Jehoulet and F. Béguin, J. Power Sources 171 (2007) 1046-1053

29) S. Ishimoto, Y. Asakawa, M. Shinya and K. Naoi, J. Electrochem. Soc. 156 (2009) A563-A571.

30) D. Cazorla-Amorós, D. Lozano-Castelló, E. Morallón, M. J. Bleda-Martínez, A. Linares-Solano and S. Shiraishi, Carbon 48 (2010) 1451-1456.

31) P. W. Ruch, D. Cericola, A. Foelske, R. Kötz and A. Wokaun, Electrochim. Acta 55 (2010) 2352-2357. 